\title{
Exotoxin diversity of Staphylococcus aureus isolated from milk of cows with subclinical mastitis in Central Russia
}

\author{
K. K. Fursova, ${ }^{*}{ }^{1}$ M. P. Shchannikova, ${ }^{*} \dagger$ I. V. Loskutova, ${ }^{*} \dagger$ A. O. Shepelyakovskaya, ${ }^{\dagger} \dagger$ A. G. Laman, $\dagger$ \\ A. M. Boutanaev, $¥$ S. L. Sokolov,§ O. A. Artem’eva, ${ }^{*}$ D. A. Nikanova, ${ }^{*}$ N. A. Zinovieva, ${ }^{*}$ and F. A. Brovko*$†$ \\ *L. K. Ernst All-Russian Research Institute of Animal Husbandry, Federal Agency of Scientific Organizations, Dubrovitsy, 142132, Russia \\ †Shemyakin and Ovchinnikov Institute of Bioorganic Chemistry, \\ łnstitute of Basic Biological Problems, and \\ $\S$ G. K. Skryabin Institute of Biochemistry and Physiology of Microorganisms, Russian Academy of Sciences, Pushchino, 142290, Russia
}

\section{ABSTRACT}

Mastitis, a major veterinary problem widespread in many regions, is caused mainly by Staphylococcus spp. However, there is no current reliable information about the role of Staphylococcus aureus and their toxins in the development of mastitis in cows in the territory of the Russian Federation. The aim of this investigation was to determine the profile of exotoxins of $S$. aureus from cow milk from farms of Central Russia. A total of 60 isolates of $S$. aureus were obtained from milk samples of cows with the subclinical form of mastitis. The exotoxin genes were identified using 2 types of PCR assays. The diversity of enterotoxin genes was studied by multiplex PCR. The percentage occurrence of enterotoxin genes was as follows: sea, $53.3 \%$; seb, $3.3 \%$; sec, $50 \%$; sed, $4 \%$; see, $46.6 \%$; seg, 70\%; sei, 10\%; selp, 3.3\%; and tsst1, $1.6 \%$. The seh gene was not detected. The genes of pore-forming toxins and phenol-soluble modulins were identified by singleplex PCR and consisted of the following: hlA, 70\%; lucS, 46.6\%; psmA, 81.6\%; psmB, $95 \%$; and $h l d, 78.3 \%$. The most abundant genes were $p s m$ (psmB, $95 \%$ ), which codes for pore-forming toxins, and seg $(70 \%)$, which codes for enterotoxins. The production of some enterotoxins in bacterial culture medium was detected by ELISA. The level of toxin production was near $1 \mathrm{ng} / \mathrm{mL}$ for SEA, SEE, SEG, SEI, SELP, and TSST- 1 and reached a maximal level of $18 \mathrm{ng} / \mathrm{mL}$ for SEE. In the present work, we show that subclinical mastitis in cows is associated with $S$. aureus in the central region of the Russian Federation. Most of the isolates containing enterotoxin genes also had cytotoxin genes.

Key words: Staphylococcus aureus, cow mastitis, enterotoxin, cytotoxin

Received October 31, 2017.

Accepted January 16, 2018.

${ }^{1}$ Corresponding author: phursova_k@rambler.ru

\section{INTRODUCTION}

Bovine mastitis is a major and widespread veterinary problem (Zhang et al., 2016). This widespread disease inflicts considerable damage on agriculture and the economy as a whole. One of the consequences of this disease is reduced productivity of animals (Hertl et al., 2014). The main cause of mastitis is Staphylococcus spp. (Barkema et al., 2006; Hummerjohann et al., 2014). In the Russian Federation, the clinical form of mastitis is diagnosed in 20 to $25 \%$ of cows; subclinical mastitis is diagnosed in more than 50\% (Artem'eva et al., 2015). Due to mastitis, annual milk production decreases every year. The specific agents frequently causing cow mastitis in the Russian Federation are Staphylococcus aureus and Staphylococcus epidermidis (Shurbuda et al., 2014; Artem'eva et al., 2015). Along with the Staphylococcus genus, a broad range of other microorganisms and viruses are associated with mastitis. Some of these microorganisms can induce the disease, whereas others can protect the host organism by inhibiting the pathogenic microflora (Falentin et al., 2016; Browne et al., 2017).

Staphylococcus spp. produce a set of exotoxins or factors of pathogenicity that include enterotoxins and cytolytic toxins. Enterotoxins represent the most common family of staphylococcal exotoxins; their direct participation in the development of subclinical and clinical forms of mastitis is well known. However, the subclinical form of mastitis is often associated with coagulase-negative staphylococci, which are not characterized by the production of enterotoxins. Staphylococcus aureus, on the other hand, is characterized by the production of enterotoxins.

Cytolytic toxins, which include hemolysins, leukocidins, and phenol-soluble modulins, play an important role in the development of mastitis. All of these toxins participate in the development of mastitis associated with Staphylococcus spp. The most studied are the hemolysins, which can lyse different types of cells, including epithelial cells, and are the main pathogenesis factor in mastitis. 
Panton-Valentine leukocidin is a 2-component toxin consisting of leukocidin S and leukocidin F. Panton-Valentine leukocidin is a cytotoxin that causes leukocyte destruction and tissue necrosis and has been detected in staphylococcal isolates associated with mastitis (Unal and Cinar, 2012).

The phenol-soluble modulins (PSM) constitute a relatively new family of cytotoxins, which are secreted, amphipathic, $\alpha$-helical peptides with various biological functions. Phenol-soluble modulins possess powerful cytolytic activity against many types of cells, including neutrophils, monocytes, erythrocytes, keratinocytes, and osteoblasts. Last, it has been shown that the isolates associated with mastitis have a high level of expression of $\delta$-toxin (Deplanche et al., 2016). The aim of this work was to study the composition of enterotoxin genes of $S$. aureus associated with subclinical mastitis from cows in Central Russia and to investigate the production of enterotoxins.

\section{MATERIALS AND METHODS}

\section{Antibodies and Toxins}

We used recombinant staphylococcal toxins (SEA, SEB, SEC, SED, SEE, SEG, SEI, SELP, and TSST-1) and their genes (sea, seb, sec, sed, see, seg, sei, selp, tsst1, seh), which were kindly provided by Y. V. Vertiev (N. F. Gamaleya Scientific Research Institute of Epidemiology and Microbiology, Russian Academy of Medical Sciences, Moscow, Russia).

Murine monoclonal antibodies to these staphylococcal toxins, as well as their conjugates with EZ-Link-SulfoNHS-LC-Biotin (Thermo Fisher Scientific, Waltham, MA), were produced earlier, and their specificity was analyzed in our previous work (Rubina et al., 2010). The monoclonal antibodies were produced in ascites fluid and purified by a combination of ammonium sulfate fractionation and ion-exchange chromatography on a mono Q column (FPLC System, Pharmacia Biotech, Uppsala, Sweden). The detailed information about immunoreagents for enterotoxin detection was published recently by Rubina et al. (2010).

\section{S. aureus Isolation}

Milk samples from Holstein cows with subclinical mastitis were collected from farms of Central Russia (Kaluzhskaya oblast) in April 2015. The samples were collected in sterile tubes after disinfecting the ostium with iodized alcohol (2.5\%), and they were transported to the laboratory under refrigeration $\left(4-8^{\circ} \mathrm{C}\right)$ in cool boxes with ice packs. All of the handlers used sterilized latex gloves.
All collected samples were analyzed on traditional microbiological media as follows: coagulase-positive staphylococci were enumerated from colonies displaying an opaque zone on Baird-Parker agar with egg yolk tellurite emulsion (HiMedia Laboratories Pvt. Ltd., Telangana, India), and hemolytic staphylococci were enumerated from colonies displaying hemolysis zones on the Azide Blood Agar Pronadisa medium (Conda, Madrid, Spain) supplemented with 5\% defibrinated sheep blood. In addition, we tested for the presence of positive plasma coagulation with rabbit dry citrate plasma (CJSC Ekolab, Moscow, Russia), and we performed biochemical identification using the API 20 Staph panel (BioMerieux, Marcy-l'Étoile, France). Staphylococcus aureus ATCC 25923 and S. aureus ATCC 6538 were used as reference strains (state collection of pathogenic microorganisms and cell cultures, Obolensk, Moscow region, Russia).

\section{DNA Isolation}

Individual isolates of $S$. aureus were cultivated in a tryptic soy broth (HiMedia Laboratories Pvt. Ltd.) at $37^{\circ} \mathrm{C}$ using an orbital shaker for 14 to $16 \mathrm{~h}$. The cell culture was centrifuged at $4,000 \times g$ for $5 \mathrm{~min}$ at $4^{\circ} \mathrm{C}$, and the cell pellet was used for DNA isolation. The culture medium was used to test SE expression by ELISA.

The individual bacterial pellet was resuspended in 0.5 $\mathrm{mL}$ of $0.01 M$ Tris-HCl (pH 8.0) containing lysostaphin $(5 \mu \mathrm{g} / \mathrm{mL})$ and RNase A $(30 \mu \mathrm{g} / \mathrm{mL})$ and incubated for $0.5 \mathrm{~h}$ at $37^{\circ} \mathrm{C}$. Proteinase $\mathrm{K}(200 \mu \mathrm{g} / \mathrm{mL})$ and SDS (1\%) were added, and the mixture was incubated for $20 \mathrm{~min}$ at $50^{\circ} \mathrm{C}$. Further deproteinization of DNA was carried out by phenol-chloroform extraction and centrifugation at $12,000 \times g$ for $10 \mathrm{~min}$. Purified DNA was precipitated from the aqueous phase by adding isopropanol to $40 \%$ ( $\mathrm{vol} / \mathrm{vol}$ ) and collected by centrifugation at 12,000 $\times g$ for $10 \mathrm{~min}$. The DNA pellet was washed with $70 \%$ (vol/vol) ethanol, dried at room temperature for $5 \mathrm{~min}$, and dissolved in $50 \mu \mathrm{L}$ of deionized water (MilliQ, Millipore Corp., Billerica, MA). The DNA extracts were analyzed by electrophoresis in a $1 \%$ agarose gel stained by ethidium bromide $(5 \mu \mathrm{g} / \mathrm{mL})$.

\section{Detection of Enterotoxin Genes}

The multiplex PCR assay was used for the detection of staphylococcal enterotoxin genes (sea, seb, sed, see, seg, seh, sei) and tsst1. Singleplex PCR for sec was carried out to avoid the overlapping between seg and $s e c$. In addition, selp was amplified separately. Primers and the sizes of the amplicons are listed in Table 1. The template DNA was amplified by thermal cycling at $94^{\circ} \mathrm{C}$ for $2 \mathrm{~min}$, followed by 30 cycles of $94^{\circ} \mathrm{C}$ for 25 
$\mathrm{s}, 50^{\circ} \mathrm{C}$ for $20 \mathrm{~s}$, and $72^{\circ} \mathrm{C}$ for $40 \mathrm{~s}$, and a final extension for $6 \mathrm{~min}$ at $72^{\circ} \mathrm{C}$. The reaction mixtures used $0.5 \mu M$ of each primer, $250 \mu M$ of deoxyribonucleotide triphosphate, and 5 units of Taq DNA polymerase (Evrogen JSC, Moscow, Russia) in a reaction volume of 50 $\mu \mathrm{L}$. Positive controls were carried out in parallel and contained template DNA with the gene of an individual toxin. Negative controls used ultrapure water instead of template DNA during PCR. The reaction mixture without the DNA matrix was used as a negative control. The PCR product was analyzed by electrophoresis in a $1.5 \%$ agarose gel stained by ethidium bromide $(5$ $\mu \mathrm{g} / \mathrm{mL}$ ). The gels were photographed under UV light using the Kodak Gel Logic 100 Imaging System (Kodak, Rochester, NY).

Sequencing of PCR products of these genes was carried out by Evrogen JSC. The DNA sequences were analyzed using the BLAST search tool (https://blast .ncbi.nlm.nih.gov/).

\section{Detection of Cytotoxin Genes}

The detection of genes of PSM ( $p s m A, p s m B, h l d)$, $\alpha$-hemolysin $(h l A)$, and Panton-Valentine leukocidin (lucS) was performed by real-time PCR. The primers for the toxin genes and the sizes of the amplification products are given in Table 1 . Due to the small sizes of the sequences for PSM (psmA1, psmA2, psmA3, psmA4, psmB1, and psmB2), which are organized into 2 separate operons (psmA1-psmA4 and psmB1-psmB2) and coded for short peptides, each operon was totally amplified. The PCR conditions were as follows: $94^{\circ} \mathrm{C}$ for $5 \mathrm{~min}$; 30 cycles of $94^{\circ} \mathrm{C}$ for $30 \mathrm{~s}, 58^{\circ} \mathrm{C}$ for $20 \mathrm{~s}$, and $72^{\circ} \mathrm{C}$ for $20 \mathrm{~s}$; and $72^{\circ} \mathrm{C}$ for $5 \mathrm{~min}$. The PCR Master Mix and SYBRGreen dye (Syntol JSC, Moscow, Russia) were used in the reactions. Melting curves analysis and random electrophoresis in a 2\% agarose gel were carried out. Each sample was amplified in triplicate. The relative values of fluorescence for each sample were calculated according to the manufacturer's recommendations. A reaction mixture without a DNA template was used as a negative control.

\section{Solid-Phase Sandwich ELISA}

The production of SEA, SEB, SEC, SED, SEE, SEG, SEI, SELP, and TSST-1 in staphylococcal culture medium was determined by ELISA. The antibody pairs for sandwich assay were selected for each toxin and used for detection. Corresponding recombinant enterotoxins

Table 1. The PCR primers and the results of assay for the presence of toxin genes in the investigated Staphylococcus aureus

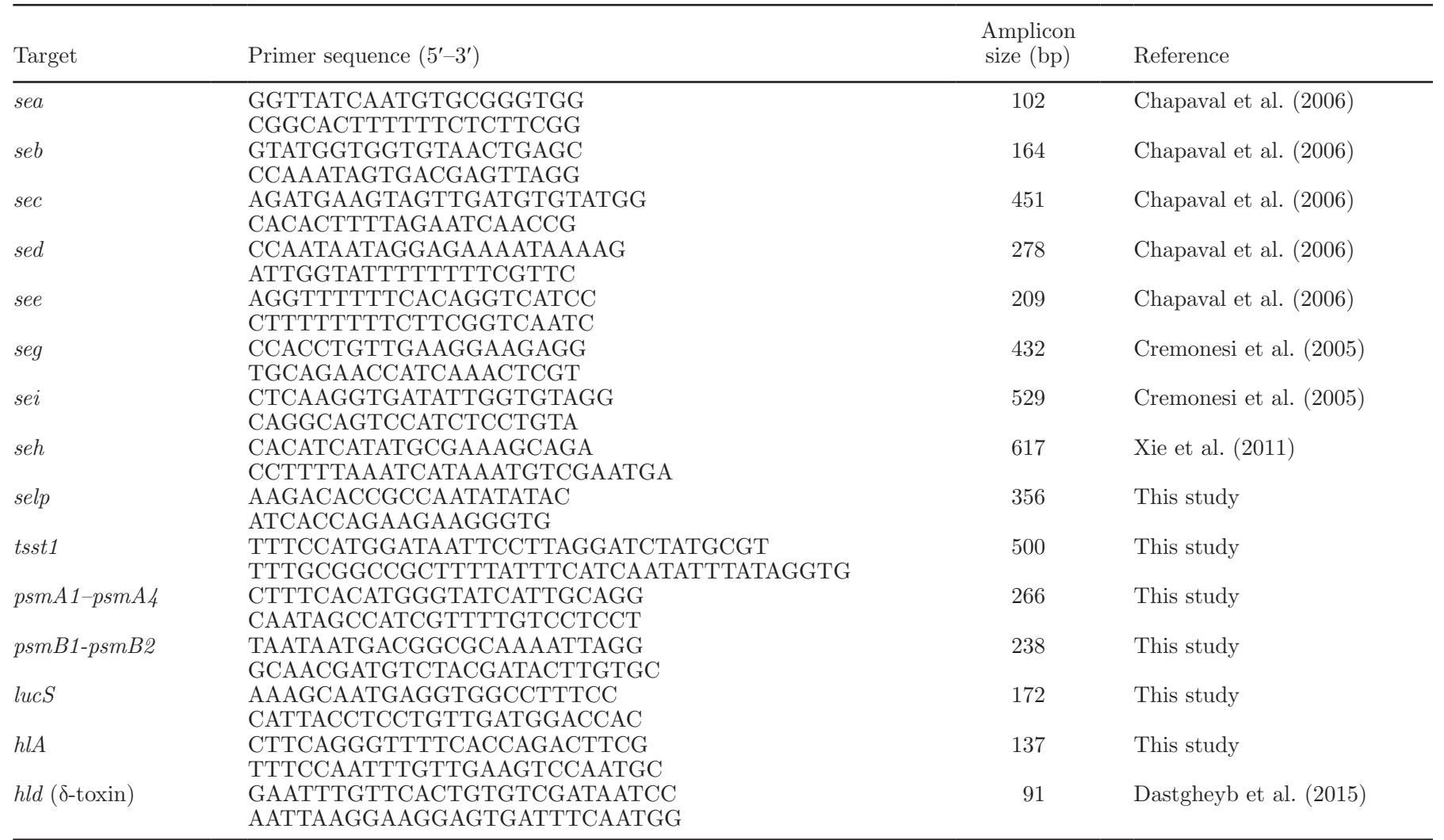


were used as positive controls. The culture medium of an $S$. aureus isolate without the enterotoxin genes was used as a negative control. The standard curves for quantitative analyses were constructed using recombinant enterotoxins. Culture supernatants of individual S. aureus isolates were preincubated with $20 \%$ (vol/ vol) normal rabbit serum at $4^{\circ} \mathrm{C}$ overnight to avoid any nonspecific reaction caused by protein A (Omoe et al., 2002). The ELISA were performed in 96-well microplates (Greiner Bio-One GmbH, Kremsmünster, Austria) using the biotin-streptavidin system for detection. We used a streptavidin conjugated with peroxidase for signal visualization (Thermo Fisher Scientific). Orthophenylenediamine hydrochloride $(0.5 \mathrm{mg} / \mathrm{mL})$ in $0.1 M$ citrate buffer ( $\mathrm{pH}$ 5.0) was used as a substrate solution, and the absorbance at $490 \mathrm{~nm}$ was read with an iMar Microplate Absorbance Reader (Bio-Rad, Hercules, CA). Data were collected from triplicate measurements of each culture. The concentration of each toxin in the culture supernatants was determined by converting the absorbance values to the corresponding concentrations by the use of a standard curve. The method was developed as described by Pujol et al. (1993) with a slight modification.

\section{RESULTS}

The multiplex PCR assay for the detection of staphylococcal enterotoxin genes was carried out for 60 isolates. Fifty-three $(88 \%)$ isolates had toxicogenic properties with the following genes identified in the corresponding number of isolates: sea in 32 (53.3\%), seb in $2(3.3 \%)$, sec in $30,(50 \%)$, sed in $3(4 \%)$, see in $28(46.6 \%)$, seg in $42(70 \%)$, sei in $6(10 \%)$, selp in 2 $(3.3 \%)$, and tsst1 in $1(1.6 \%)$ isolate (Table 1). The seh gene was not identified. Simultaneous detection of seg and $s e i$ was observed in 5 isolates. The genes encoding SEG, SEC, and SEA toxins were the most abundant (Figure 1).

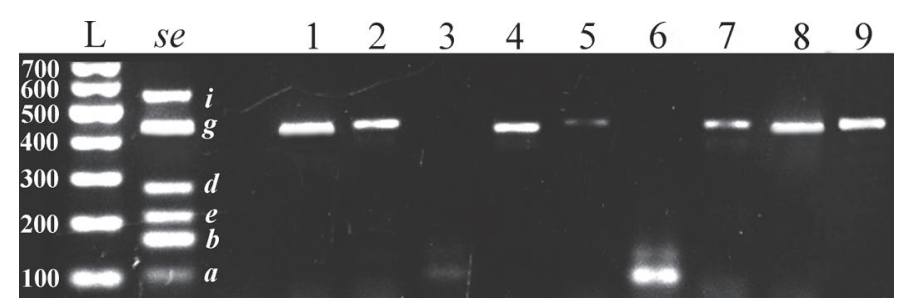

Figure 1. Polymerase chain reaction amplification of staphylococcal enterotoxin genes in Staphylococcus aureus isolates. Products of multiplex PCR in 1.5\% agarose gel. $\mathrm{L}=$ GeneRuler DNA Ladder Mix (Fermentas, Waltham, MA); se = marker of toxin genes; lanes 1 to $8=$ PCR products of $S$. aureus isolates; lane $9=$ sec gene (control marker).
The sequences of se and tsst1 genes were determined. The AA sequences were confirmed to correspond to GenBank accession numbers: SEA, AAA26681.1; SEB, EXP38233.1; SEC, BAF78878.1; SED, ANJ16443.1; SEE, AAA26617.1; SEI, EYO43459.1; SEG, EHT83812.1; SELP, EWO51483.1; and TSST-1, AAL71885.1.

The results of PCR for detecting the presence of genes encoding PSM and pore-forming toxins were as follows: $h l A, 70 \%$; lucS, $46.6 \%$; psmA, $81.6 \%$; psmB, $95 \%$; and $h l d, 78.3 \%$. Considering the fact that the presence of genes does not guarantee their expression, we analyzed the ability of isolates to produce enterotoxins and TSST-1. All isolates containing the seb, sed, see, sei, selp, and tsst1 genes were analyzed. For isolates that contained the sea, sec, see, and seg genes, 10 isolates were selected for the expression analysis of each gene. Each isolate that contained the sea, see, seg, sei, selp, and tsst1 genes was capable of expressing the corresponding enterotoxin. Production of SEG in the culture medium did not exceed $1 \mathrm{ng} / \mathrm{mL}$, SELP did not exceed $0.5 \mathrm{ng} / \mathrm{mL}$, and SEA did not exceed 0.5 to $1 \mathrm{ng} / \mathrm{mL}$. Concentrations of SEI in the culture medium ranged from 1 up to $4 \mathrm{ng} / \mathrm{mL}$, and SEE concentrations ranged from 1 up to $10 \mathrm{ng} / \mathrm{mL}$. The concentration of TSST- 1 was $0.3 \mathrm{ng} / \mathrm{mL}$, and TSST- 1 was detected only once. Two isolates were characterized by simultaneous coexpression of 2 enterotoxins: SEE and SEI for isolate number 13, and SEE and SEG for isolate number 66. Another 2 isolates were able to simultaneously express 3 enterotoxins: TSST-1, SEG, and SEI for isolate number 17 and SEI, SEG, and SEE for isolate number 9 (Figure 2). The highest level of expression was detected for isolate number 66, which produced SEE at $18 \mathrm{ng} /$ $\mathrm{mL}$. The production of SEB, SEC, and SED was not detected in any isolate, although the corresponding genes were identified.

\section{DISCUSSION}

Cow mastitis is a common infectious disease both in the territory of the Russian Federation and around the world. In Russia, more than $20 \%$ of cows are discarded after the disease due to atrophy of one or several quarters of the udder. Because of mastitis, the annual herd yield is reduced by 8 to $12 \%$ (Artem'eva et al., 2015).

Studying the problem of mastitis and its associated pathogens is a current focus of research. Staphylococcus aureus plays an important role in the development of this disease. The presence of $S$. aureus in samples isolated from cows with subclinical mastitis varies from $4.8 \%$ in Brazil to $28.6 \%$ in Turkey (Karahan et al., 2009; Rall et al., 2014). It is considered usual to find enterotoxin genes in $S$. aureus isolated from affected 
Isolate

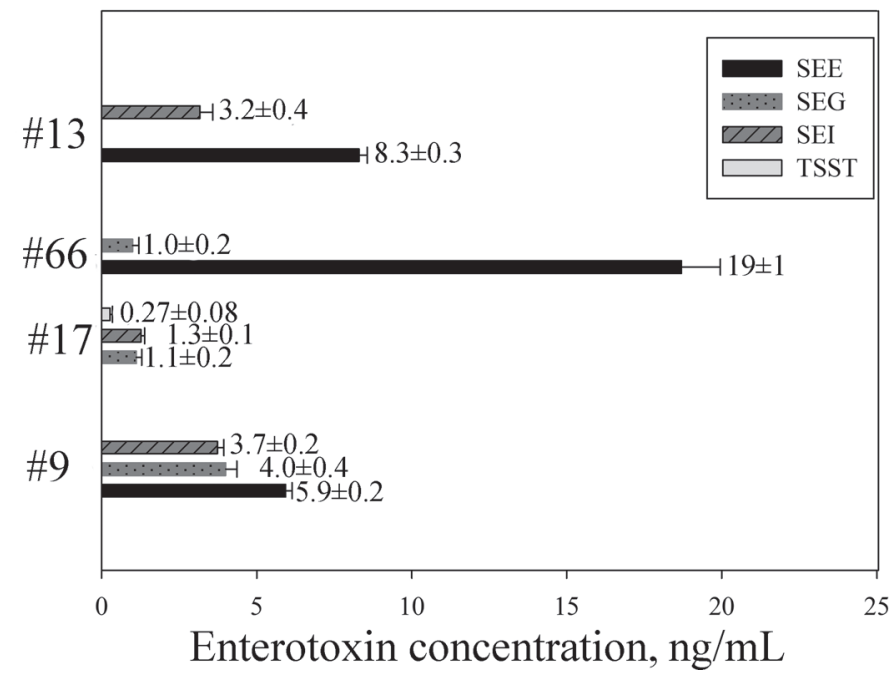

Figure 2. Detection of enterotoxins in the culture medium of Staphylococcus aureus isolates by sandwich ELISA. Recombinant enterotoxins were used as positive controls. Culture media of isolates without enterotoxin genes were used as negative controls. The $S$. $a u$ reus isolates were cultivated in vitro at $37^{\circ} \mathrm{C}$ with aeration for 14 to 16 h. Culture supernatants were preincubated with $20 \%$ (vol/vol) normal rabbit serum before analysis by sandwich ELISA. Data are from triplicate measurements of each culture and presented as the mean $\pm \mathrm{SD}$.

animals in various regions (Mello et al., 2016; Rola et al., 2016; Wang et al., 2016). However, data on the prevalence of staphylococcal exotoxins in the Russian Federation are very limited. In the present work, we investigated the presence of exotoxin genes in $S$. aureus isolates from cows with subclinical mastitis and analyzed the ability to express some of these genes.

One of the main enterotoxin genes of $S$. aureus isolated from cows with mastitis is sea. We detected sea in 32 $(53.3 \%)$ isolates; sea was not the dominant enterotoxin gene among the isolates that we analyzed, but it was present at a high level. In previously published studies, this gene occurred at rates ranging from 23.6 to $50 \%$ (Rall et al., 2014).

The major enterotoxin gene in our investigation turned out to be seg. It was detected in $42(70 \%)$ isolates. In previous works of other authors, this gene was detected at rates ranging from 30 to $40 \%$ of isolates (Wang et al., 2009; Rall et al., 2014). Despite the fact that the seg and sei genes are localized together in the egc cluster, we detected the sei gene in only $10 \%$ of our isolates.

High levels of detection were observed for the sec and see genes, which were detected at rates of 50 and $46.6 \%$ of our isolates, respectively. Based on previous work, these genes are rarely present in cow mastitis. The presence of the sec gene varied from almost $10 \%$ of coagulase-negative staphylococci to 9 to $20 \%$ of $S$. aureus (Rola et al., 2015). The see enterotoxin gene has not been found in previous related works (Wang et al., 2009; Rola et al., 2015). Despite the fact that pathogenicity islands can carry the sec-sell-tst genes, in our case, tsst1 was detected in $1.6 \%$ of the isolates.

All other enterotoxin genes were rarely present: seb in $2(3.3 \%)$, sed in $3(4 \%)$, and selp in $2(3.3 \%)$ of the isolates. In addition, despite the previously demonstrated important role of SEH, we did not detect its gene; SEH is the inducer of mammary epithelial cell apoptosis (Liu et al., 2014), and thus this toxin plays an important role in the mastitis process.

Staphylococcal exotoxins can act in a cooperative manner by influencing both the mammary tissues and the immune system of the animal. Thus, the next step of our work was the detection of cytotoxin genes. A significant amount of effort has been devoted to studying the role of $\alpha$-hemolysin in mastitis development (Vandenesch et al., 2012). We were able to identify the $h l A$ gene in $70 \%$ of the isolates. In a previous work, Wang et al. (2016) showed that $94 \%$ of staphylococcal isolates associated with mastitis contain the $h l A$ gene. The occurrence of the $h l A$ gene exceeded one-third of the investigated samples in an Italian region (Artursson et al., 2016). In addition, the high lethality associated with hemolysin production was shown on a murine model of mastitis caused by S. aureus (Bramley et al., 1989). The specific feature of the $\alpha$-toxin is its ability to kill neutrophils, which are important constituents of natural immunity (Abtin et al., 2014). This effect of hemolysin production has been described for skin infections and presumably should occur at their site of action on mammary tissues.

Previous work of Unal and Cinar (2012) reported that the $p v l$ gene was detected in $5 \%$ of coagulase-negative staphylococcal isolates. However, earlier works found a spread of 0 to $56 \%$ (Zecconi et al., 2006; Aires-de-Sousa et al., 2007). Here, we detected the lukS gene in $46.6 \%$ of our isolates.

The psm genes were the most commonly detected among our isolates. The gene $p s m A$ was identified in $81.6 \%, p s m B$ in $95 \%$, and the gene of the $\delta$-toxin ( $h l d)$ in $78.3 \%$ of the isolates. These peptide toxins play an important role in mastitis. According to Deplanche et al. (2016), PSM activate host immune system cells by regulating the spectrum and level of production of lymphokines. However, PSM have a wider range of functional activities, including their roles in quorum sensing, regulating the activity of the genes of staphylococcal virulence factors, and suppressing competitive microorganisms (Peschel and Otto, 2013; Joo et al., 2016).

Of great interest is the ability of isolates to produce enterotoxins. Considering that not all toxins are se- 
creted into the culture medium (Oliveira et al., 2011), we tested for the actual capability of our isolates to produce enterotoxins. We analyzed the enterotoxin production levels in some isolates that contained enterotoxins genes. We found that all investigated isolates had a very low level of SE production. We also detected a minimal level of expression of TSST-1 $(0.3 \mathrm{ng} / \mathrm{mL})$, which was identified for 1 isolate. The maximal level of production was detected for SEE, which reached $18 \mathrm{ng} / \mathrm{mL}$. The production of SEB, SEC, and SED in the culture medium was not confirmed. However, we found that $3.3,50$, and $4 \%$ of our isolates contained the seb, sec, and sed genes, respectively. The loss of toxin production, despite the presence of the enterotoxin gene, was described earlier by other authors (Rall et al., 2014). However, such a characteristic is inherent to coagulase-negative staphylococci. The combination of exotoxin genes determined in our isolates suggests a high potential for mastitis induction and necessitates further investigation into how they may cooperate to induce and develop mastitis in cows.

\section{CONCLUSIONS}

In the present work, we showed that subclinical mastitis in cows is associated with S. aureus in the central region of the Russian Federation. Enterotoxin genes were identified, and we detected the potential ability to express several of these genes. In addition, most of the isolates containing enterotoxin genes also had cytotoxin genes. We assume that such co-occurrence represents a cooperative process that plays an important role in the development of mastitis due to $S$. aureus invasion of the tissue of the mammary glands.

\section{ACKNOWLEDGMENTS}

The work was carried out within the framework of grant no. 15-16-00020 under the agreement with the Russian Science Foundation (Moscow). We declare no conflicts of interest for this work.

\section{REFERENCES}

Abtin, A., R. Jain, A. J. Mitchell, B. Roediger, A. J. Brzoska, S. Tikoo, Q. Cheng, L. G. Ng, L. L. Cavanagh, U. H. von Andrian, M. J. Hickey, N. Firth, and W. Weninger. 2014. Perivascular macrophages mediate neutrophil recruitment during bacterial skin infection. Nat. Immunol. 15:45-53. https://doi.org/10.1038/ni.2769.

Aires-de-Sousa, M., C. E. S. R. Parente, O. Vieira-da-Motta, I. C. F. Bonna, D. A. Silva, and H. de Lencastre. 2007. Characterization of Staphylococcus aureus isolates from buffalo, bovine, ovine, and caprine milk samples collected in Rio de Janeiro State, Brazil. Appl. Environ. Microbiol. 73:3845-3849. https://doi.org/10.1128/ AEM.00019-07.

Artem'eva, O. A., D. A. Pereselkova, I. V. Vinogradova, E. N. Kotkovskaya, E. A. Gladyr', N. V. Sivkin, and N. A. Zinovieva. 2015.
Screening of dairy cows' herd for the presence of hemolytic microorganisms in milk in relation to somatic cell content. [In Russian.] Agric. Biol. 50:810-816. https://doi.org/10.15389/agrobiology .2015.6.810rus.

Artursson, K., R. Söderlund, L. Liu, S. Monecke, and J. Schelin. 2016. Genotyping of Staphylococcus aureus in bovine mastitis and correlation to phenotypic characteristics. Vet. Microbiol. 193:156-161. https://doi.org/10.1016/j.vetmic.2016.08.012.

Barkema, H. W., Y. H. Schukken, and R. N. Zadoks. 2006. The role of cow, pathogen, and treatment regimen in the therapeutic success of bovine Staphylococcus aureus mastitis. J. Dairy Sci. 89:1877-1895.

Bramley, A. J., A. H. Patel, M. O'Reilly, R. Foster, and T. J. Foster. 1989. Roles of alpha-toxin and beta-toxin in virulence of Staphylococcus aureus for the mouse mammary gland. Infect. Immun. 57:2489-2494.

Browne, H. P., B. A. Neville, S. C. Forster, and T. D. Lawley. 2017. Transmission of the gut microbiota: Spreading of health. Nat. Rev Microbiol. 15:531-543. https://doi.org/10.1038/nrmicro.2017.50.

Chapaval, L., D. H. Moon, J. E. Gomes, F. R. Duarte, and S. M. Tsai. 2006. Use of PCR to detect classical enterotoxin genes (ent) and toxic shock syndrome toxin-1 gene (tst) in Staphylococcus aureus isolated from crude milk and determination of toxin productivities of Staph. aureus isolates harboring these genes. Arq. Inst. Biol. (Sao Paulo) 73:165-169.

Cremonesi, P., M. Luzzana, M. Brasca, S. Morandi, R. Lodi, C. Vimercati, D. Agnellini, G. Caramenti, P. Moroni, and B. Castiglioni. 2005. Development of a multiplex PCR assay for the identification of Staphylococcus aureus enterotoxigenic strains isolated from milk and dairy products. Mol. Cell. Probes 19:299-305.

Dastgheyb, S. S., A. E. Villaruz, K. Y. Le, V. Y. Tan, A. C. Duong, S. S. Chatterjee, G. Y. Cheung, H. S. Joo, N. J. Hickok, and M. Otto. 2015. Role of phenol-soluble modulins in formation of Staphylococcus aureus biofilms in synovial fluid. Infect. Immun. 83:2966-2975. https://doi.org/10.1128/IAI.00394-15.

Deplanche, M., L. Alekseeva, K. Semenovskaya, C. L. Fu, F. Dessauge, L. Finot, W. Petzl, H. Zerbe, Y. Le Loir, P. Rainard, D. G. Smith, P. Germon, M. Otto, and N. Berkova. 2016. Staphylococcus aureus phenol-soluble modulins impair interleukin expression in bovine mammary epithelial cells. Infect. Immun. 84:1682-1692. https:// doi.org/10.1128/IAI.01330-15.

Falentin, H., L. Rault, A. Nicolas, D. S. Bouchard, J. Lassalas, P. Lamberton, J. M. Aubry, P. G. Marnet, Y. Le Loir, and S. Even. 2016. Bovine teat microbiome analysis revealed reduced alpha diversity and significant changes in taxonomic profiles in quarters with a history of mastitis. Front. Microbiol. 7:480. https://doi.org/ 10.3389/fmicb.2016.00480.

Hertl, J. A., Y. H. Schukken, F. L. Welcome, L. W. Tauer, and Y. T. Gröhn. 2014. Pathogen-specific effects on milk yield in repeated clinical mastitis episodes in Holstein dairy cows. J. Dairy Sci. 97:1465-1480. https://doi.org/10.3168/jds.2013-7266.

Hummerjohann, J., J. Naskova, A. Baumgartner, and H. U. Graber. 2014. Enterotoxin-producing Staphylococcus aureus genotype B as a major contaminant in Swiss raw milk cheese. J. Dairy Sci. 97:1305-1312. https://doi.org/10.3168/jds.2013-7643.

Joo, H. S., S. S. Chatterjee, A. E. Villaruz, S. W. Dickey, V. Y. Tan, Y. Chen, D. E. Sturdevant, S. M. Ricklefs, and M. Otto. 2016. Mechanism of gene regulation by a Staphylococcus aureus toxin. mBio 7:e01579-16. https://doi.org/10.1128/mBio.01579-16.

Karahan, M., M. N. Açik, and B. Cetinkaya. 2009. Investigation of toxin genes by polymerase chain reaction in Staphylococcus aureus strains isolated from bovine mastitis in Turkey. Foodborne Pathog. Dis. 6:1029-1035. https://doi.org/10.1089/fpd.2009.0304.

Liu, Y., W. Chen, T. Ali, R. Alkasir, J. Yin, G. Liu, and B. Han. 2014 Staphylococcal enterotoxin $\mathrm{H}$ induced apoptosis of bovine mammary epithelial cells in vitro. Toxins (Basel) 6:3552-3567.

Mello, P. L., D. F. Moraes Riboli, L. Pinheiro, L. de Almeida Martins, M. A. Vasconcelos Paiva Brito, and M. de Lourdes Ribeiro de Souza da Cunha. 2016. Detection of enterotoxigenic potential and determination of clonal profile in Staphylococcus aureus and coagulase-negative staphylococci isolated from bovine subclinical 
mastitis in different Brazilian states. Toxins (Basel) 8:104. https:// doi.org/10.3390/toxins8040104.

Oliveira, L., A. C. Rodrigues, C. Hulland, and P. L. Ruegg. 2011. Enterotoxin production, enterotoxin gene distribution, and genetic diversity of Staphylococcus aureus recovered from milk of cows with subclinical mastitis. Am. J. Vet. Res. 72:1361-1368. https://doi .org/10.2460/ajvr.72.10.1361.

Omoe, K., M. Ishikawa, Y. Shimoda, D. L. Hu, S. Ueda, and K. Shinagawa. 2002. Detection of seg, seh, and sei genes in Staphylococcus aureus isolates and determination of the enterotoxin productivities of $S$. aureus isolates harboring seg, seh, or sei genes. J. Clin. Microbiol. 40:857-862.

Peschel, A., and M. Otto. 2013. Phenol-soluble modulins and staphylococcal infection. Nat. Rev. Microbiol. 11:667-673. https://doi.org/ 10.1038/nrmicro3110.

Pujol, F. H., I. Rodriguez, M. Devesa, R. Rangel-Aldao, and F. J. Liprandi. 1993. A double sandwich monoclonal enzyme immunoassay for detection of hepatitis B surface antigen. J. Immunoassay 14:21-31. https://doi.org/10.1080/15321819308019838.

Rall, V. L., E. S. Miranda, I. G. Castilho, C. H. Camargo, H. Langoni, F. F. Guimarães, J. P. Araújo Júnior, and A. Fernandes Júnior. 2014. Diversity of Staphylococcus species and prevalence of enterotoxin genes isolated from milk of healthy cows and cows with subclinical mastitis. J. Dairy Sci. 97:829-837. https://doi.org/10 .3168/jds.2013-7226.

Rola, J. G., A. Czubkowska, W. Korpysa-Dzirba, and J. Osek. 2016. Occurrence of Staphylococcus aureus on farms with small scale production of raw milk cheeses in Poland. Toxins (Basel) 8:E62. https://doi.org/10.3390/toxins8030062.

Rola, J. G., W. Korpysa-Dzirba, A. Czubkowska, and J. Osek. 2015. Prevalence of enterotoxin genes and antimicrobial resistance of coagulase-positive staphylococci recovered from raw cow milk. J. Dairy Sci. 98:4273-4278. https://doi.org/10.3168/jds.2014-9064.

Rubina, A. Yu., M. A. Filippova, G. U. Feizkhanova, A. S. Zasedatelev, A. O. Shepeliakovskaya, E. I. Sidina, K. M. Boziev, A. G. Laman, F. A. Brovko, E. V. Grishin, and Y. V. Vertiev. 2010. Simultaneous detection of seven staphylococcal enterotoxins: Development of hydrogel biochips for analytical and practical application. Anal. Chem. 82:8881-8889.
Shurbuda, N. A., V. M. Sotnikova, M. V. Ryzhova, I. S. Osipova, and S. V. Tokarev. 2014. The species composition of the raw milk microflora isolated from cow udder secretion in healthy cows and cows with bovine mastitis. [In Russian.] Problems Vet. San. Hygiene Ecol. 2:65-67.

Unal, N., and O. D. Cinar. 2012. Detection of stapylococcal enterotoxin, methicillin-resistant and Panton-Valentine leukocidin genes in coagulase-negative staphylococci isolated from cows and ewes with subclinical mastitis. Trop. Anim. Health Prod. 44:369-375. https://doi.org/10.1007/s11250-011-0032-x.

Vandenesch, F., G. Lina, and T. Henry. 2012. Staphylococcus aureus hemolysins, bi-component leukocidins, and cytolytic peptides: A redundant arsenal of membrane-damaging virulence factors? Front. Cell. Infect. Microbiol. 2:12. https://doi.org/10.3389/fcimb .2012.00012.

Wang, S. C., C. M. Wu, S. C. Xia, Y. H. Qi, L. N. Xia, and J. Z. Shen. 2009. Distribution of superantigenic toxin genes in Staphylococcus aureus isolates from milk samples of bovine subclinical mastitis cases in two major diary production regions of China. Vet. Microbiol. 137:276-281. https://doi.org/10.1016/j.vetmic.2009.01.007.

Wang, D., L. Zhang, X. Zhou, Y. He, C. Yong, M. Shen, O. Szenci, and B. Han. 2016. Antimicrobial susceptibility, virulence genes, and randomly amplified polymorphic DNA analysis of Staphylococcus aureus recovered from bovine mastitis in Ningxia, China. J. Dairy Sci. 99:9560-9569. https://doi.org/10.3168/jds.2016-11625.

Xie, Y., Y. He, A. Gehring, Y. Hu, Q. Li, S.-I. Tu, and X. Shi. 2011. Genotypes and toxin gene profiles of Staphylococcus aureus clinical isolates from China. PLoS One 6:e28276. https://doi.org/10.1371/ journal.pone.0028276.

Zecconi, A., L. Cesaris, E. Liandris, V. Daprà, and R. Piccinini. 2006. Role of several Staphylococcus aureus virulence factors on the inflammatory response in bovine mammary gland. Microb. Pathog. 40:177-183. https://doi.org/10.1016/j.micpath.2006.01.001.

Zhang, Z., X. P. Li, F. Yang, J. Y. Luo, X. R. Wang, L. H. Liu, and H. S. Li. 2016. Influences of season, parity, lactation, udder area, milk yield, and clinical symptoms on intramammary infection in dairy cows. J. Dairy Sci. 99:6484-6493. https://doi.org/10.3168/ jds.2016-10932. 